\title{
Genetic Variation at the Catalytic Subunit of Glutamate Cysteine Ligase Contributes to the Susceptibility to Colorectal Cancer: A Pilot Study
}

\author{
Marina Bykanova ( $\square$ marina.bickanova@yandex.ru) \\ Kursk State Medical University: Kurskij Gosudarstvennyj Medicinskij Universitet https://orcid.org/0000-0001-5420-3557 \\ Maria Solodilova \\ Kursk State Medical University: Kurskij Gosudarstvennyj Medicinskij Universitet \\ Iuliia Azarova \\ Kursk State Medical University: Kurskij Gosudarstvennyj Medicinskij Universitet \\ Elena Klyosova \\ Kursk State Medical University: Kurskij Gosudarstvennyj Medicinskij Universitet \\ Olga Bushueva \\ Kursk State Medical University: Kurskij Gosudarstvennyj Medicinskij Universitet \\ Anna Polonikova \\ Kursk State Medical University: Kurskij Gosudarstvennyj Medicinskij Universitet \\ Mikhail Churnosov \\ Belgorod State University: Belgorodskij gosudarstvennyj nacional'nyj issledovatel'skij universitet \\ Alexey Polonikov \\ Kursk State Medical University: Kurskij Gosudarstvennyj Medicinskij Universitet
}

\section{Research Article}

Keywords: colorectal cancer, carcinogenesis, genetic predisposition to disease, single nucleotide polymorphism, glutamate cysteine ligase, glutathione.

Posted Date: January 27th, 2022

DOI: https://doi.org/10.21203/rs.3.rs-1253021/v1

License: (9) This work is licensed under a Creative Commons Attribution 4.0 International License. Read Full License 


\section{Abstract}

Background. Glutathione is a tripeptide detoxifying a variety of exogenous and endogenous free radicals and carcinogens, and a deficiency of glutathione is associated with an increased host susceptibility to oxidative stress, a pathological condition implicated in the development and progression of cancer. Catalytic subunit of glutamate-cysteine ligase (GCLC) is enzyme responsible for initial and rate-limiting step of glutathione biosynthesis.

Methods and results. The aim of this pilot study was to investigate whether genetic variation at the GCLC gene contributes to the risk of colorectal cancer (CRC). DNA samples from 681 unrelated Russian individuals (283 patients with CRC and 398 age- and sex-matched healthy controls) were genotyped for seven common single nucleotide polymorphisms (SNPs) such as rs12524494, rs17883901, rs606548, rs636933, rs648595 and rs761142 of the GCLC gene using the MassARRAY-4 system. We found that genotype rs606548-C/T is significantly associated with increased risk of CRC regardless sex and age $(\mathrm{OR}=2.24 ; 95 \% \mathrm{Cl} 1.24-4.03$; $P=0.007$, FDR=0.04). Moreover, ten GCLC genotype combinations showed association with the risk of $\mathrm{CRC}(\mathrm{P}<0.05)$. Functional SNP annotation enabled establishing the CRC-associated polymorphisms are associated with a decreased GCLC expression that may be attributed to epigenetic effects of histone modifications operating in a colon-specific manner.

Conclusions. The present study was the first to show that genetic variation at the catalytic subunit of glutamate-cysteine ligase may contribute to the risk of colorectal cancer risk. However further genetic association studies with a larger sample size are required to substantiate the role of GCLC gene polymorphisms in the development of colorectal cancer.

\section{Introduction}

Colorectal cancer (CRC) is the third most common malignant tumor and the second cause of death attributed to cancer worldwide [1, 2]. About 1.9 million new cases of CRC and 935000 deaths have been recorded in the world in 2020 [3]. The incidence of this cancer type is higher in developed countries than in countries with emerging economies, and the incidence rate of CRC is progressively growing in many countries of the world, including the Russian Federation [4].

Colorectal cancer is a multifactorial disease resulting from interactions between genetic and environmental factors such as a lack of regular physical activity, cigarette smoking, alcohol consumption, and various dietary factors $[4,5,6]$. Moreover, substances with carcinogenic activity such as drugs, pesticides, food additives, and chemicals released during food cooking have been found to increase the risk of colorectal cancer. A large number of candidate gene and genome-wide association studies have been done to investigate the role of genetic factors in CRC susceptibility, and numerous single nucleotide polymorphisms (SNPs) have been identified to be associated with disease risk $[8,9,10]$. There exists increasing evidence that dietary factors such as low consumption of fruits, vegetables, and fibers, high-fat diet, a diet high in processed meats play an important role in the development of CRC and therefore dietary modification is promised to reduce disease incidence $[4,11,12]$. Anti-carcinogenic properties of fruits and vegetables, as well as unprocessed meats, are attributed to numerous natural components in this type of food among which glutathione is of particular importance.

Glutathione (GSH) is an intracellular thiol peptide (consists of three amino acids such as cysteine, glycine, and glutamic acid) that presents in the majority of cell types at high concentrations, and is involved in xenobiotic detoxification, antioxidant defense, maintenance of mitochondrial function, and modulation of cellular proliferation, inhibition of apoptosis in many other crucial biological functions $[13,14]$. Since glutathione is known to detoxify a wide variety of exogenous and endogenous carcinogens and free radicals, and this function makes GSH a powerful molecule protecting from carcinogenesis $[15,16]$. Importantly, glutathione deficiency is associated with increased susceptibility to oxidative stress implicated in the development and progression of cancer $[17,18]$. In the context of the anti-carcinogenic function of GSH, Shiraishi with co-authors reported that long-term ingestion of reduced glutathione (GSH) was found to suppress an accelerating effect of beef tallow diet on colon carcinogenesis in rats [19]. Hoensch with co-workers [20] observed that glutathione levels in the large intestine are relatively low and decrease from proximal (the colon transversum) to a distal colon (sigma). Genetic polymorphisms for glutathione metabolism enzymes may explain interindividual differences in glutathione biosynthesis and thus influence susceptibility to colorectal cancer. Thus, polymorphic genes encoding enzymes involved in the glutathione biosynthesis like glutamate-cysteine ligase (GCL) are attractive biomarkers for testing the genetic susceptibility to colorectal cancer. However, the contribution of genes responsible for glutathione 
biosynthesis such as GCLC, a catalytic subunit of glutamate-cysteine ligase, catalyzing the initial rate-limiting step of GSH biosynthesis [21], to the predisposition to colorectal cancer has not so far been investigated. Therefore, the purpose of this pilot study was to investigate whether common SNPs at the GCLC gene are associated with the risk of colorectal cancer in a population of Central Russia.

\section{Material And Methods Study participants}

The Ethical Review Committee of Kursk State Medical University has approved the research protocol. All participants gave written informed consent before enrollment for this study. A total of 681 unrelated individuals ( 283 patients with CRC and 398 healthy controls) from Central Russia were recruited for the study. The patients were enrolled from the Kursk Regional Oncological Dispensary during the period between 2013 and 2016. The diagnosis of CRC was verified by experienced oncologists based on the results of clinical, laboratory, and instrumental methods. The control group was recruited from the same population and included healthy blood volunteers and hospital-based patients with no clinical evidence for CRC, as described previously [22, 23]. The criterion for inclusion in the control group was the absence of oncological and other chronic diseases.

\section{DNA analysis}

Whole blood samples $(5 \mathrm{~mL})$ were collected from all study participants into EDTA-coated tubes and maintained at -200C until processed. Genomic DNA was isolated using the standard procedure of phenol-chloroform extraction. Six common functional SNPs of the GCLC gene (minor allele frequency in the European population is higher than 5\%) such as rs 12524494 , rs 17883901, rs606548, rs636933, rs648595, and rs761142 were selected for the study using SNPinfo, GenePipe, and FuncPred bioinformatics tools [24], as described previously [7]. Genotyping of the SNPs was performed with the MassArray-4 system (Agena Bioscience Inc, San Diego, CA, USA) at the Research Institute for Genetic and Molecular Epidemiology of Kursk State Medical University (Kursk, Russia). To ensure quality control, $10 \%$ of the samples were chosen at random for repeat genotyping, which was performed blindly to the case-control status, and the repeatability test yielded a $100 \%$ concordance rate.

\section{Statistical and bioinformatics analysis}

Allele frequencies were estimated by the gene counting method. The chi-square test was applied to assess significant departures of genotype frequency from Hardy-Weinberg equilibrium (HWE). P-value $\leq 0.05$ was considered statistically significant. Allele and genotype frequencies and their association with CRC groups were analyzed using the SNPStats software [25] available online at https://snpstats.net. SNP-disease associations were evaluated by multiple logistic regression (codominant genetic model) with the calculation of odds ratios (ORs) and $95 \%$ confidence intervals $(95 \% \mathrm{Cl})$ adjusted for covariates such as age and sex. SNPStats software was also used to estimate GCLC haplotypes and their association with CRC risk, as well as to assess linkage disequilibrium (LD, $D$, and $D^{\prime}$ values) between SNPs. Genotype combinations were compared between the study groups using the chi-square test, and the method of false discovery rate (FDR) was applied to all SNP-disease associations to control for multiple testing (FDR calculator available online at http://www.sdmproject.com/utilities/?show=FDR).

Publically available bioinformatics databases and online resources such as eQTLGen Consortium (https://www.eqtlgen.org), GTEx portal (https://gtexportal.org), and VannoPortal (http://www.mulinlab.org/vportal/index.html) were used to annotate the studied polymorphisms of the GCLC gene. The bioinformatics analysis was aimed to assess whether the studied GCLC gene polymorphisms are significant quantitate trait loci (QTL) that correlate with molecular traits such as mRNA expression (eQTL) and histone modification (hQTL).

\section{Results}

\section{Allele and genotype frequencies of the GCLC polymorphisms in the studied population}


The mean age of the case and control groups were $66.13 \pm 10.02$ and $66.08 \pm 5.27$ years, respectively $(P=0.93)$. The number of males was similar in the case $(N=146,51.59 \%)$ and control $(N=228,57.29 \%)$ groups $(P=0.61)$. The genotype and allele frequencies are shown in Table 1. The genotype distribution for all studied polymorphisms of the GCLC gene was in the Hardy-Weinberg equilibrium ( $P>0.05)$. Minor allele frequencies (MAF) for SNPs rs 12524494 and rs606548 were in accordance with those reported in European populations (www.ensembl.org), as a part of the 1000 Genomes Project. However, MAF for SNPs rs17883901, rs636933, rs648595, and rs761142 of GCLC in the Russian population differed significantly $(P \leq 0.05)$ from the European one.

\section{Association of the GCLC polymorphisms with the risk of colorectal cancer}

Statistically significant difference in minor allele frequencies for SNPs rs606548 $(P=0.041)$ and rs761142 (P=0.032) of the GCLC gene were observed between the case and control groups. A carriage of genotype rs606548-C/T $(\mathrm{OR}=2.24 ; 95 \% \mathrm{Cl} 1.24-4.03$; $P=0.007$ ) was associated with increased risk of colorectal cancer regardless sex and age (overdominant effect of SNP). Furthermore, SNP rs761142 (OR=1.30; $95 \% \mathrm{Cl} 1.01-1.66 ; P=0.041)$ of $G C L C$ showed an association with increased susceptibility to colorectal cancer (log-additive SNP effect).

\section{Joint effects of the GCLC polymorphisms on CRC susceptibility}

Table 2 shows genotype combinations associated with the risk of colorectal cancer. As can be seen from Table 2, eight out ten genotype combinations were associated with increased risk of CRC. The disease high risk of these genotype combinations were attributed to the presence of heterozygotes such as rs12524494-G/A, rs636933-G/A, rs648595-G/T, and rs606548-C/T. In contrast, two genotype combinations such as rs636933-G/G. rs761142-A/A (G3) and rs606548-C/C. rs17883901-G/G (G9) were protective against the risk of CRC. However, this association did not survive after correction for multiple testing using the FDR procedure.

We estimated haplotype frequencies in CRC patients and controls (Supplementary table 1). No difference was observed in the haplotype distribution between the study groups $(\mathrm{P}>0.05)$. Supplementary table 2 shows data on linkage disequilibrium between the studied SNPs in the Russian population. SNPs rs12524494 and rs636933 were in positive linkage disequilibrium $\left(D^{\prime}=0.812\right.$, $P=0.0011$ ). SNPs pairs such as rs606548 and rs761142, rs12524494 and rs761142 were in strong linkage disequilibrium $\left(D^{\prime}=0.9987, D^{\prime}=9114\right)$.

\section{Functional annotation for CRC-associated polymorphisms of the GCLC gene}

Functional annotation of the studied SNPs was done using the Vannovar bioinformatics tools (Table 3). We found that all the polymorphisms represent functional genetic variants through which expression levels of the GCLC gene might be modulated in the colon and rectal cells. SNPs rs12524494 and rs606548 were subject of great interest since the variants showed association with CRC susceptibility. The polymorphisms of the GCLC gene were predicted as likely pathogenic variants with oncogenicity scores. VannoPortal data on regulatory chromatin states from DNase-Seq, ATAC-seq, histone ChIP-Seq, and selected transcription factor ChIP-seq from 869 biosamples, as a part of the Epimap Epigenomics 2021 project were analyzed [26]. It is observed that SNP rs12524494 is associated with histone mark H3K36me3 (the tri-methylation at the 36th lysine residue to the DNA packaging protein Histone $\mathrm{H} 3$ ) in malignant cell types such as lung epithelial and hepatocellular carcinoma, sarcoma, melanoma, B cell lymphoma, acute lymphoblastic leukemia, testicular embryonal carcinoma, eye retinoblastoma, neuroblastoma. In addition, rs12524494 is associated with epigenetic modification H3K79me2 (the di-methylation at the 79th lysine residue of the histone H3 protein) in lung epithelial carcinoma. SNP rs12524494 was found to be associated with strong gene transcription in mucosal cells of the colon and rectum (Roadmap Epigenomics) and also related with epigenetic modification H3K36me3. Importantly, 3D Genomes data from VannoPortal show that SNP rs12524494 is associated with enhancer/promoter activity of GCLC and AL033397.2 miRNA (antisense) in colorectal adenocarcinoma epithelial cells. The analysis of the Epimap Epigenomics data showed that SNP rs606548 is associated with histone marks such as H3K79me2 and H4K20me1 in colorectal adenocarcinoma cells. H4K20me1 (the mono-methylation at the 20th lysine residue of the histone $\mathrm{H} 4$ protein) is associated with transcriptional activation and is important for cell cycle regulation [27]. According to the Roadmap Epigenomics data, polymorphism rs606548 of the GCLC gene is associated with a weak transcriptional activity in mucosal cells of the colon and rectum as well as with histone mark H3K79me2 which in turn is associated with enhancer/promoter activity of GCLC in colorectal adenocarcinoma epithelial cells, as identified by the 3D Genomes project.

Page $4 / 15$ 
Tissue-specific eQTL data on the polymorphisms of the GCLC gene of VannoPortal were analyzed. In addition, the bioinformatics databases such as eQTLGen and the GTEx mRNA expression in different tissues and whole-genome genotype data were also used to assess the functional effects of the SNPs. Table 4 shows tissue-specific eQTL analysis for polymorphisms of the GCLC gene. In the whole blood, allele rs 12524494-G is associated with decreased levels of GCLC (eQTLGen Consortium, Q<0.001) and increased levels of pseudogene ERHP2 (VannoPortal, Q=8.44×10-4). Allele rs606548-T is associated with decreased expression of $G C L C$ in whole blood (eQTLGen Consortium, Q<0.001) and increased expression of ELOVL5 (VannoPortal, Q =1.44×10-7) in neutrophils and monocytes, as assessed on the transcriptomic data of Chen with co-workers [28]. Allele rs761142-C is associated with decreased expression of GCLC in the whole blood. Thus, none of the CRC-associated polymorphisms are associated with expression levels of GCLC in both sigmoid and transverse parts of the colon.

Tissue and cell type-specific prioritization of regulatory variants that are in the linkage disequilibrium with the CRC-associated GCLC gene polymorphisms has revealed that these variants are likely regulated in both colonic mucosa and sigmoid colon through epigenetic mechanisms, as predicted by the VannoPortal tool (VarNote-REG V1.1) on the 1000 Genomes Project, Phase 3 (data of European ancestry). In particular, SNP rs761142 is associated with histone mark H3K79me2 (REG score=0.86537) and is in LD with a variant rs9474579 associated with histone marks such as H3K27ac, H3K4me2, and H3K79me2 (REG score=0.87631) in mucosal cells of the colon. In the sigmoid colon, SNP rs9474579 linked to the rs761142 variant is also associated with histone marks such as H3K27ac, H3K4me2, and H3K79me2 (REG score=0.87631). The regulatory variants rs17885586 (REG score $=0.88625$ ), rs1555907 (REG score $=0.78026$ ) and rs1555906 (REG score $=0.74814$ ) linked to the rs761142 polymorphism are associated with histone mark $\mathrm{H} 3 \mathrm{~K} 79 \mathrm{me} 2$, whereas a regulatory variant rs2268326 (REG score $=0.75310$ ) is associated with histone mark H3K4me2.

In the colon mucosa, polymorphism rs 12524494 is linked with numerous regulatory variants that are an object for epigenetic regulation. For instance, a tightly linked SNP rs2268329 $\left(D^{\prime}=0.9441\right)$ is associated (REG score $\left.=0.90309\right)$ with histone marks such as H3K27ac, H3K4me1, H3K4me2, H3K79me2, and H3K4me3 as well as represents a DNase hypersensitivity site. In the sigmoid colon, nine regulatory variants (rs16883893, rs16883924, rs17881289, rs2300422, rs2268329, rs3799699, rs3799698, rs606548 and rs77802486) linked with SNP rs12524494 are associated (REG score>0.674) with histone marks such as H3K36me3, H3K79me2 and H3K4me2.

SNP rs606548 is linked to six regulatory variants (rs77802486, rs4715408, rs16883924, rs3799698, rs3799699 and rs2284650) which are associated with histone marks H3K79me2 and H3K36me3 in colon mucosal cells. In the sigmoid colon, nine rs606548linked regulatory variants (rs16883893, rs2268329, rs77802486, rs16883924, rs17881289, rs2300422, rs3799698, rs3799699 and rs2284650) are associated (REG score>0.676) with histone marks H3K79me2, H3K4me2 and H3K36me3.

The 3D Genomes data from VannoPortal show that the CRC-associated polymorphisms rs 12524494 , rs606548, and rs761142 are associated with enhancer/promoter activity of GCLC in colorectal adenocarcinoma epithelial cells. In addition, all these SNPs are associated with the weak transcriptional activity of the GCLC gene in mucosal cells of the colon, as assessed by regulatory chromatin states from the DNase-Seq and histone ChIP-Seq data of the Roadmap Epigenomics Project (VannoPortal).

\section{Discussion}

Glutathione is a tripeptide, $\gamma$-L-glutamyl-L-cysteinyl glycine, present in all tissues at high $(1-10 \mathrm{mM})$ concentrations and is considered as the most abundant non-protein thiol antioxidant playing a critical role in maintaining redox homeostasis and defending the cell against oxidative damage $[14,29,30]$. GSH possesses numerous vital functions in the cell such as detoxifying xenobiotics, scavenging free radicals, maintaining the essential thiol status of proteins, providing a reservoir for cysteine, as well as modulating critical cellular processes such as DNA synthesis, microtubule dynamics, and immune function [14, 31]. The major determinants of intracellular GSH production are the availability of cysteine, the sulfur amino acid determining the activity of glutamate-cysteine ligase (GCL), the rate-limiting enzyme of glutathione biosynthesis. GCL is composed of a catalytic (GCLC) and modifier (GCLM) subunits which are differentially regulated [30].

The levels of reduced glutathione were found to be elevated in numerous types of human cancers such as bone marrow [32], breast [33], and lung [34] as well as colorectal cancer [21]. Moreover, the increased expression of GCLChas been identified in lung, breast, liver, and other types of cancer [35]. It is observed that the increased resistance to chemotherapeutic drugs and radiation

Page 5/15 
therapy might be associated with increased levels of GSH [36], suggesting that increased glutathione is a secondary event when tumor cells somehow enhance glutathione biosynthesis to ensure their vital functions. In addition, the levels of GCLC were found to be overexpressed in patients with liver metastases, where the enzyme is thought to promote tumor cell survival under hypoxic and cell-dense conditions [37]. Nguyen with co-workers [38] observed that the RNAi-mediated inhibition of glutathione synthesis impaired survival of multiple colon cancer cell lines.

The present study was the first to identify significant associations between polymorphisms of GCLC and the risk of CRC. In particular, a polymorphism rs 606548 of GCLC showed a significant association with the risk of colorectal cancer in the Russian population regardless of age and sex. Two other SNPs of the GCLC gene such as rs12524494 and rs761142 showed a weak association with disease risk, and the association did not survive after correction for multiple tests. Furthermore, ten genotype GCLC combinations were associated with the risk of CRC. Functional SNP annotation using multiple bioinformatics tools revealed that polymorphisms rs606548, rs12524494, and rs761142, despite being located in non-coding regions of the gene, represent the regulatory variants that themselves or due to their tightly linked SNPs may impact the expression level of the GCLC through epigenetic mechanisms such as histone modification and DNase sensitivity.

According to the literature, GCLC gene polymorphisms are known to be associated with breast and prostate cancer [39, 40]. In particular, SNP s12524494 is associated with susceptibility to breast cancer [41]. Polymorphism rs761142 of GCLC is found to affect drug metabolism, but no evidence for association with any type of cancer was observed [42]. Polymorphism rs17883901 $[43,44]$, rs41303970, and rs12524494 [7] were found to be associated with the risk of diabetes. Interestingly, ELOVL5 whose decreased expression level in the sigmoid part of the colon is correlated with allele rs17883901-A of GCLC (data obtained from GTEx portal), was found to be highly expressed in colorectal cancer tissues [45]. It is proposed that changes in expression may be indicative of the increased regulation of fatty acid biosynthesis that contributes to the reprogramming of cellular phospholipidome and membrane alterations in colon cancer [46]. There is also evidence for an association between polymorphism rs606548 of the GCLC gene and the risk of ischemic stroke [47]. Bioinformatics analysis allowed identifying that the CRC-associated alleles are associated with decreased expression of the GCLC gene, and the modulating effects of these variants, most likely, are realized through epigenetic mechanisms including histone modifications operating in a tissue-specific manner [48]. We propose that histone modifications such as H3K79me2, H3K4me2, and H3K36me3 as well as H3K79me2 and H3K36me3 might contribute to the weak transcriptional activity of the GCLC gene in the sigmoid part of colon and colon mucosa, respectively. Taking together our findings suggest that the decreased transcription of the GCLC gene in the carriers for the rs 606548 variant and associated decreased levels of glutathione makes mucosal cells of the colon more sensitive to environmental carcinogens.

\section{Study limitations}

The present study has a limitation in that the results were obtained with a relatively small number of CRC patients and healthy controls. The link between polymorphisms of GCLC and colorectal cancer observed in the studied population of relatively low sample size should be considered as an exploratory finding highlighting the demand in validation in a larger independent population with a focus on a wider spectrum of polymorphisms of the GCLC gene. Moreover, the present study did analyze geneenvironment interactions, a joint effect of the GCLC gene polymorphisms, and well-recognized environmental factors such as hypodynamia, cigarette smoking, alcohol consumption, and dietary factors on the risk of colorectal cancer.

In conclusion, the present study is the first to show an association between single nucleotide polymorphisms and the risk of colorectal cancer. Based on the observed associations, we suppose that the GCLC gene may contribute to the CRC susceptibility through a diminished biosynthesis of glutathione in the large intestine where the tripeptide is crucial for the regulation of multiple cellular processes, including cell differentiation, proliferation, and apoptosis as well as for the detoxification and removal of carcinogens and free radicals leading to oxidative stress that has been implicated in cancer development and progression [18, 49]. However, before drawing a definitive conclusion on the roles of the GCLC gene in colorectal cancer, further studies with a larger sample size are required to confirm the association between the gene polymorphisms to the risk of colorectal cancer and to investigate whether environmental factors modify the effects of SNPs on the disease susceptibility. Better understanding the impact of the GCLC gene polymorphisms on glutathione biosynthesis and their contribution to colorectal cancer susceptibility will open new avenues for disease prevention through glutathione replenishment and provide opportunities for effective genotypebased treatment of disease progression [50]. 


\section{Declarations}

Funding This study was supported by the TRC GEN+ Genetic Research Foundation of Trans Russian Co (contract no. 474). Competing Interests The authors have no relevant financial or non-financial interests to disclose. Ethical approval All procedures performed in studies involving human participants were in accordance with the ethical standards of the institutional research committee and with the 1964 Helsinki declaration and its later amendments or comparable ethical standards. Consent to publish Informed consent was obtained from all individual participants included in the study. ACKNOWLEDGEMENTS This study was supported by the TRC GEN+ Genetic Research Foundation of Trans Russian Co (contract no. 474).

\section{References}

1.Ferlay J., Soerjomataram I., Dikshit R. et al. Cancer incidence and mortality worldwide: sources, methods and major patterns in GLOBOCAN 2012 // Intern. J. Cancer. 2015. V. 136. № 5. P. E359-E386. https://doi.org/10.1002/ijc.29210

2.Sung H, Ferlay J, Siegel RL, Laversanne M, Soerjomataram I, Jemal A, Bray F. Global Cancer Statistics 2020: GLOBOCAN Estimates of Incidence and Mortality Worldwide for 36 Cancers in 185 Countries. CA Cancer J Clin. 2021 May;71(3):209-249. doi: $10.3322 /$ caac. 21660 .

3.Ferlay J, Colombet M, Soerjomataram I, Parkin DM, Piñeros M, Znaor A, Bray F. Cancer statistics for the year 2020: An overview. Int J Cancer. 2021 Apr 5. doi: 10.1002/ijc.33588.

4.Keum N, Giovannucci E. Global burden of colorectal cancer: emerging trends, risk factors and prevention strategies. Nat Rev GastroenterolHepatol. 2019 Dec;16(12):713-732. doi: 10.1038/s41575-019-0189-8.

5.Aran V., Victorino A.P., Thuler L.C., Ferreira C.G. Colorectal cancer: epidemiology, disease mechanisms and interventions to reduce onset and mortality // Clin. Colorectal Cancer. 2016. V. 15. № 3. P. 195-203. https://doi.org/10.1016/j.clcc.2016.02.008

6.Wan ML, Wang Y, Zeng Z, Deng B, Zhu BS, Cao T, Li YK, Xiao J, Han Q, Wu Q. Colorectal cancer (CRC) as a multifactorial disease and its causal correlations with multiple signaling pathways. Biosci Rep. 2020 Mar 27;40(3):BSR20200265. doi:

10.1042/BSR20200265.

7.Azarova I, Klyosova E, Lazarenko V, Konoplya A, Polonikov A. Genetic variants in glutamate cysteine ligase confer protection against type 2 diabetes. MolBiol Rep. 2020 Aug;47(8):5793-5805. doi: 10.1007/s11033-020-05647-5.

8.Fearon ER. Molecular genetics of colorectal cancer. Annu Rev Pathol. 2011; 6:479-507. doi: 10.1146/annurev-pathol-011110130235.

9.Siegert S, Hampe J, Schafmayer C, von Schönfels W, Egberts JH, Försti A, Chen B, Lascorz J, Hemminki K, Franke A, Nothnagel M, Nöthlings U, Krawczak M. Genome-wide investigation of gene-environment interactions in colorectal cancer. Hum Genet. 2013 Feb;132(2):219-31. doi: 10.1007/s00439-012-1239-2.

10.Zeng C, Matsuda K, Jia WH, Chang J, Kweon SS, Xiang YB, Shin A, Jee SH, Kim DH, Zhang B, Cai Q, Guo X, Long J, Wang N, Courtney R, Pan ZZ, Wu C, Takahashi A, Shin MH, Matsuo K, Matsuda F, Gao YT, Oh JH, Kim S, Jung KJ, Ahn YO, Ren Z, Li HL, Wu J, Shi J, Wen W, Yang G, Li B, Ji BT; Genetics and Epidemiology of Colorectal Cancer Consortium (GECCO), Brenner H, Schoen RE, Küry S; Colorectal Transdisciplinary (CORECT) Study, Gruber SB, Schumacher FR, Stenzel SL; Colon Cancer Family Registry (CCFR), Casey G, Hopper JL, Jenkins MA, Kim HR, Jeong JY, Park JW, Tajima K, Cho SH, Kubo M, Shu XO, Lin D, Zeng YX, Zheng W. Identification of Susceptibility Loci and Genes for Colorectal Cancer Risk. Gastroenterology. 2016 Jun; 150(7):1633-1645. doi: 10.1053/j.gastro.2016.02.076.

11.Song M, Garrett WS, Chan AT. Nutrients, foods, and colorectal cancer prevention. Gastroenterology. 2015 May;148(6):124460.e16. doi: 10.1053/j.gastro.2014.12.035.

12.Murphy N, Moreno V, Hughes DJ, Vodicka L, Vodicka P, Aglago EK, Gunter MJ, Jenab M. Lifestyle and dietary environmental factors in colorectal cancer susceptibility. Mol Aspects Med. 2019 Oct;69:2-9. doi: 10.1016/j.mam.2019.06.005.

Page $7 / 15$ 
13.Wu G, Fang YZ, Yang S, Lupton JR, Turner ND. Glutathione metabolism and its implications for health. J Nutr. 2004 Mar;134(3):489-92. doi: 10.1093/jn/134.3.489.

14.Pizzorno J. Glutathione! Integr Med (Encinitas). 2014 Feb;13(1):8-12.

15.Richie JP Jr. The role of glutathione in aging and cancer. ExpGerontol. 1992 Sep-Dec;27(5-6):615-26. doi: 10.1016/05315565(92)90015-r.

16.Richie JP Jr, Komninou D, Albino AP. Induction of colon tumorigenesis by glutathione depletion in p53-knock-out mice. Int J Oncol. 2007 Jun; 30(6):1539-43.

17.Jones DP, Coates RJ, Flagg EW, Eley JW, Block G, Greenberg RS, Gunter EW, Jackson B. Glutathione in foods listed in the National Cancer Institute's Health Habits and History Food Frequency Questionnaire. Nutr Cancer. 1992;17(1):57-75. doi: 10.1080/01635589209514173.

18. Traverso N, Ricciarelli R, Nitti M, Marengo B, Furfaro AL, Pronzato MA, Marinari UM, Domenicotti C. Role of glutathione in cancer progression and chemoresistance. Oxid Med Cell Longev. 2013;2013:972913. doi: 10.1155/2013/972913.

19.Shiraishi R, Fujise T, Kuroki T, Kakimoto T, Miao L, Sakata Y, Tsunada S, Noda T, Iwakiri R, Fujimoto K. Long-term ingestion of reduced glutathione suppressed an accelerating effect of beef tallow diet on colon carcinogenesis in rats. J Gastroenterol. 2009; 44 (10):1026-35. doi: 10.1007/s00535-009-0101-3.

20. Hoensch H, Peters WH, Roelofs HM, Kirch W. Expression of the glutathione enzyme system of human colon mucosa by localisation, gender and age. Curr Med Res Opin. 2006 Jun;22(6):1075-83. doi: 10.1185/030079906X112480.

21.Kim AD, Zhang R, Han X, Kang KA, Piao MJ, Maeng YH, Chang WY, Hyun JW. Involvement of glutathione and glutathione metabolizing enzymes in human colorectal cancer cell lines and tissues. Mol Med Rep. 2015 Sep;12(3):4314-4319. doi: 10.3892/mmr.2015.3902.

22.Moskalev A.S., Barysheva E.M., Soldatov V.O., Frolova O.G., Bobyntseva O.V., Samgina T.A., Churnosov M.I., Ivanov V.P., Polonikov A.V., BushuevaO.Yu. Association of C3435T (rs1045642) Polymorphism of the MDR1 Gene with the Increased Risk of Colorectal Cancer in Russian Females from Central Russia. Russian Journal of Genetics, 2019, Vol. 55, No. 12, pp. $1514-1519$.

23.Moskalev AS. Association of L432V (rs1056836) polymorphism of the CYP1B1 gene with the increased risk of colorectal cancer in the population of Central Russia. Research Results in Biomedicine. 2020;6(3):318-322.

24.Polonikov AV, KlyosovaEYu, Azarova IE. Bioinformatic tools and internet resources for functional annotation of polymorphic loci detected by genome wide association studies of multifactorial diseases (review). Research Results in Biomedicine.2021;7(1):1531. DOI: 10.18413/2658-6533-2020-7-1-0-2

25.Solé X, Guinó E, Valls J, Iniesta R, Moreno V. SNPStats: a web tool for the analysis of association studies. Bioinformatics. 2006 Aug 1;22(15):1928-9. doi: 10.1093/bioinformatics/btl268.

26.Hoon DSB, Rahimzadeh N, Bustos MA. EpiMap: Fine-tuning integrative epigenomics maps to understand complex human regulatory genomic circuitry. Signal Transduct Target Ther. 2021 May 8;6(1):179. doi: 10.1038/s41392-021-00620-5.

27.Wang Z, Zang C, Rosenfeld JA, Schones DE, Barski A, Cuddapah S, Cui K, Roh TY, Peng W, Zhang MQ, Zhao K. Combinatorial patterns of histone acetylations and methylations in the human genome. Nat Genet. 2008 Jul;40(7):897-903. doi: 10.1038/ng.154.

28.Chen L, Ge B, Casale FP, Vasquez L, Kwan T, Garrido-Martín D, Watt S, Yan Y, Kundu K, Ecker S, Datta A, Richardson D, Burden F, Mead D, Mann AL, Fernandez JM, Rowlston S, Wilder SP, Farrow S, Shao X, Lambourne JJ, Redensek A, Albers CA, Amstislavskiy V, Ashford S, Berentsen K, Bomba L, Bourque G, Bujold D, Busche S, Caron M, Chen SH, Cheung W, Delaneau O, Dermitzakis ET, Elding H, Colgiu I, Bagger FO, Flicek P, Habibi E, lotchkova V, Janssen-Megens E, Kim B, Lehrach H, Lowy E, Mandoli A, Matarese F, Maurano MT, Morris JA, PancaldiV, Pourfarzad F, Rehnstrom K, Rendon A, Risch T, Sharifi N, Simon MM, Sultan M, Valencia A, Walter K, Wang SY, Frontini M, Antonarakis SE, Clarke L, Yaspo ML, Beck S, Guigo R, Rico D, Martens JHA, Ouwehand WH, Kuijpers 
TW, Paul DS, Stunnenberg HG, Stegle O, Downes K, Pastinen T, Soranzo N. Genetic Drivers of Epigenetic and Transcriptional Variation in Human Immune Cells. Cell. 2016 Nov 17;167(5):1398-1414.e24. doi: 10.1016/j.cell.2016.10.026.

29.Sies H. Glutathione and its role in cellular functions. Free RadicBiol Med. 1999 Nov;27(9-10):916-21. doi: 10.1016/s08915849(99)00177-x.

30.Lu SC. Regulation of glutathione synthesis. Mol Aspects Med. 2009 Feb-Apr;30(1-2):42-59. doi: 10.1016/j.mam.2008.05.005.

31.Suthanthiran M. et al. Glutathione regulates activation-dependent DNA synthesis in highly purified normal human T lymphocytes stimulated via the CD2 and CD3 antigens //Proceedings of the National Academy of Sciences. - 1990. - T. 87. - №. 9. - C. 3343-3347.

32.Joncourt F, Oberli-Schrämmli AE, Stadler M, Buser K, Franscini L, Fey MF, Cerny T. Patterns of drug resistance parameters in adult leukemia. Leuk Lymphoma. 1995 Mar;17(1-2):101-9. doi: 10.3109/10428199509051709.

33.Jardim BV, Moschetta MG, Leonel C, Gelaleti GB, Regiani VR, Ferreira LC, Lopes JR, Zuccari DA. Glutathione and glutathione peroxidase expression in breast cancer: an immunohistochemical and molecular study. Oncol Rep. 2013 Sep;30(3):1119-28. doi: 10.3892/or.2013.2540.

34.Cook JA, Pass HI, lype SN, Friedman N, DeGraff W, Russo A, Mitchell JB. Cellular glutathione and thiol measurements from surgically resected human lung tumor and normal lung tissue. Cancer Res. 1991 Aug 15;51(16):4287-94.

35.Mougiakakos D, Okita R, Ando T, Dürr C, Gadiot J, Ichikawa J, Zeiser R, Blank C, Johansson CC, Kiessling R. High expression of GCLC is associated with malignant melanoma of low oxidative phenotype and predicts a better prognosis. J Mol Med (Berl). 2012 Aug;90(8):935-44. doi: 10.1007/s00109-012-0857-4.

36.Nguyen LN, Munshi A, Hobbs ML, Story MD, Meyn RD. Paclitaxel restores radiation-induced apoptosis in a bcl-2-expressing, radiation-resistant lymphoma cell line. Int J RadiatOncolBiol Phys. 2001 Mar 15;49(4):1127-32. doi: 10.1016/s03603016(00)01435-8.

37.Bolger, J. C., McCartan, D., Walsh, C. A., Hao, Y., Hughes, E., Byrne, C., ... \& Young, L. S. (2012, December). Global analysis of breast cancer metastasis suggests cellular reprogramming is central to the endocrine resistant phenotype. In CANCER RESEARCH (Vol. 72). 615 CHESTNUT ST, 17TH FLOOR, PHILADELPHIA, PA 19106-4404 USA: AMER ASSOC CANCER RESEARCH.

38.Nguyen A, Loo JM, Mital R, Weinberg EM, Man FY, Zeng Z, Paty PB, Saltz L, Janjigian YY, de Stanchina E, Tavazoie SF. PKLR promotes colorectal cancer liver colonization through induction of glutathione synthesis. J Clin Invest. 2016 Feb;126(2):681-94. doi: $10.1172 / \mathrm{JCl} 83587$.

39. Rodrigues P, Furriol J, Bermejo B, Chaves FJ, Lluch A, Eroles P. Identification of candidate polymorphisms on stress oxidative and DNA damage repair genes related with clinical outcome in breast cancer patients. Int J Mol Sci. 2012 Dec 5;13(12):16500-13. doi: 10.3390/ijms131216500.

40.Koutros S, Andreotti G, Berndt SI, Hughes Barry K, Lubin JH, Hoppin JA, Kamel F, Sandler DP, Burdette LA, Yuenger J, Yeager M, Alavanja MC, Freeman LE. Xenobiotic-metabolizing gene variants, pesticide use, and the risk of prostate cancer. Pharmacogenet Genomics. 2011 Oct;21(10):615-23. doi: 10.1097/FPC.0b013e3283493a57.

41.Xiong, Momiao. "Linkage Disequilibrium and Test for Interaction Between Two Loci." Current Topics in Human Genetics: Studies in Complex Diseases (2007): 209.

42.Guerra, Ricardo. Adverse Cutaneous Drug Eruptions: Review of Immunology, Pathogenesis, and Pharmacogenomics With Focus on HIV and TEN. Diss. Harvard University, 2018.

43.Vieira SM, Monteiro MB, Marques T, Luna AM, Fortes MA, Nery M, Queiroz M, Dib SA, Vendramini MF, Azevedo MJ, Canani LH, Parisi MC, Pavin EJ, Giannella-Neto D, Corrêa-Giannella ML. Association of genetic variants in the promoter region of genes 
encoding p22phox (CYBA) and glutamate cysteine ligase catalytic subunit (GCLC) and renal disease in patients with type 1 diabetes mellitus. BMC Med Genet. 2011 Sep 30;12:129. doi: 10.1186/1471-2350-12-129.

44.Perez RV, Machado CG, Santos-Bezerra DP, Admoni SN, Patente TA, Monteiro MB, Cavaleiro AM, Queiroz MS, Nery M, CorrêaGiannella ML. Allelic variations in genes belonging to glutathione system increase proliferative retinopathy risk in type 1 diabetes individuals. Gene. 2019 Jun 30;703:120-124. doi: 10.1016/j.gene.2019.04.015.

45.Hama K, Fujiwara Y, Hayama T, Ozawa T, Nozawa K, Matsuda K, Hashiguchi Y, Yokoyama K. Very long-chain fatty acids are accumulated in triacylglycerol and nonesterified forms in colorectal cancer tissues. Sci Rep. 2021 Mar 17;11(1):6163. doi: 10.1038/s41598-021-85603-w.

46. Hofmanová J, Slavík J, Ciganek M, Ovesná P, Tylichová Z, Karasová M, Zapletal O, Straková N, Procházková J, Bouchal J, Kolář Z, Ehrmann J, Levková M, Hušková Z, Skalický P, Kozubík A, Machala M, Vondráček J. Complex Alterations of Fatty Acid Metabolism and Phospholipidome Uncovered in Isolated Colon Cancer Epithelial Cells. Int J Mol Sci. 2021 Jun 22;22(13):6650. doi: $10.3390 /$ ijms22136650.

47.Bocharova, Y. A. "Associations between glutamate cysteine ligase catalytic subunit gene polymorphisms and clinical characteristics of ischemic stroke." Bulletin of Russian State Medical University 1 (2021): 19-23.

48.Pekowska A, Benoukraf T, Ferrier P, Spicuglia S. A unique H3K4me2 profile marks tissue-specific gene regulation. Genome Res. 2010 Nov;20(11):1493-502. doi: 10.1101/gr.109389.110.

49. Hussain SP, Hofseth LJ, Harris CC. Radical causes of cancer. Nat Rev Cancer. 2003 Apr;3(4):276-85. doi: 10.1038/nrc1046.

50.Fedorinov DS, Lyadov VK, Sychev DA. Genotype-based chemotherapy for patients with gastrointestinal tumors: focus on oxaliplatin, irinotecan, and fluoropyrimidines. Drug MetabPersTher. 2021 Nov 30. doi: 10.1515/dmdi-2021-0162.

\section{Tables}

Table 1 Genotype and allele frequencies for the studied gene polymorphisms of GCLC among CRC patients and healthy controls 


\begin{tabular}{|c|c|c|c|c|c|c|c|}
\hline SNP ID & Genotype, allele & $\begin{array}{l}\text { Controls, } \\
\mathrm{n}(\%)^{1}\end{array}$ & $\begin{array}{l}\text { CRC patients, } \\
\mathrm{n}(\%)^{1}\end{array}$ & $\begin{array}{l}\text { OR } \\
(95 \% \mathrm{Cl})^{2}\end{array}$ & $\begin{array}{l}P \text { - } \\
\text { value }^{2}\end{array}$ & $\begin{array}{l}\text { adj } \mathrm{OR} \\
(95 \% \mathrm{Cl})^{3}\end{array}$ & $P$-value ${ }^{3}$ \\
\hline rs12524494 & $\mathrm{A} / \mathrm{A}$ & 335 (92.8) & 249 (89.6) & 1.00 & \multirow[t]{5}{*}{0.034} & 1.00 & \multirow[t]{5}{*}{0.028} \\
\hline \multirow[t]{6}{*}{$A>G$} & $A / G$ & 23 & 29 & 1.70 & & 1.74 & \\
\hline & & $(6.4)$ & $(10.4)$ & $(0.96-3.00)$ & & $(0.98-3.08)$ & \\
\hline & $\mathrm{G} / \mathrm{G}$ & 3 & 0 & NA & & NA & \\
\hline & & $(0.8)$ & $(0.0)$ & & & & \\
\hline & G & 0.040 & 0.052 & 1.31 & \multirow[t]{2}{*}{0.31} & 1.77 & \multirow[t]{2}{*}{0.30} \\
\hline & & & & $(0.78-2.23)$ & & $(0.45-1.30)$ & \\
\hline rs17883901 & $\mathrm{G} / \mathrm{G}$ & 327 (84.7) & $225(82.1)$ & 1.00 & \multirow[t]{5}{*}{0.62} & 1.00 & \multirow[t]{5}{*}{0.64} \\
\hline \multirow[t]{6}{*}{$\mathrm{G}>\mathrm{A}$} & $\mathrm{G} / \mathrm{A}$ & 57 & 48 & 1.22 & & 1.22 & \\
\hline & & $(14.8)$ & $(17.5)$ & $(0.80-1.86)$ & & $(0.80-1.86)$ & \\
\hline & $\mathrm{A} / \mathrm{A}$ & 2 & 1 & 0.73 & & 0.74 & \\
\hline & & $(0.5)$ & $(0.4)$ & $(0.07-8.06)$ & & $(0.07-8.24)$ & \\
\hline & $A$ & 0.079 & 0.091 & 1.17 & \multirow[t]{2}{*}{0.43} & 1.19 & \multirow[t]{2}{*}{0.41} \\
\hline & & & & $(0.79-1.73)$ & & $(0.76-1.77)$ & \\
\hline \multirow{7}{*}{$\begin{array}{l}r s 606548 \\
C>T\end{array}$} & $\mathrm{C} / \mathrm{C}$ & $346(93.8)$ & $234(88.6)$ & 1.00 & \multirow[t]{5}{*}{0.013} & 1.00 & \multirow[t]{5}{*}{0.008} \\
\hline & $\mathrm{C} / \mathrm{T}$ & 21 & 30 & 2.11 & & 2.23 & \\
\hline & & $(5.7)$ & (11.4) & $(1.18-3.78)$ & & $(1.24-4.01)$ & \\
\hline & \multirow[t]{2}{*}{$\mathrm{T} / \mathrm{T}$} & 2 & 0 & \multirow[t]{2}{*}{ NA } & & NA & \\
\hline & & $(0.5)$ & $(0.0)$ & & & & \\
\hline & \multirow[t]{2}{*}{$\mathrm{T}$} & 0.034 & 0.057 & 1.72 & \multirow[t]{2}{*}{0.048} & 1.74 & \multirow[t]{2}{*}{0.041} \\
\hline & & & & $(1.00-2.96)$ & & $(1.01-2.99)$ & \\
\hline \multirow{7}{*}{$\begin{array}{l}\text { rs636933 } \\
\text { G>A }\end{array}$} & $\mathrm{G} / \mathrm{G}$ & $244(64.2)$ & $162(58.1)$ & 1.00 & \multirow[t]{5}{*}{0.26} & 1.00 & \multirow[t]{5}{*}{0.3} \\
\hline & $\mathrm{G} / \mathrm{A}$ & 119 (31.3) & 104 (37.3) & 1.32 & & 1.30 & \\
\hline & & & & $(0.95-1.83)$ & & $(0.93-1.81)$ & \\
\hline & \multirow[t]{2}{*}{$\mathrm{A} / \mathrm{A}$} & 17 & 13 & 1.15 & & 1.14 & \\
\hline & & $(4.5)$ & $(4.7)$ & $(0.54-2.44)$ & & $(0.54-2.42)$ & \\
\hline & \multirow[t]{2}{*}{ A } & 0.201 & 0.233 & 1.21 & \multirow[t]{2}{*}{0.17} & 1.19 & \multirow[t]{2}{*}{0.18} \\
\hline & & & & $(0.92-1.57)$ & & $(0.90-1.61)$ & \\
\hline \multirow{6}{*}{$\begin{array}{l}\mathrm{rs} 648595 \\
T>G\end{array}$} & $\mathrm{~T} / \mathrm{T}$ & $130(33.5)$ & 85 & 1.00 & \multirow[t]{6}{*}{0.6} & 1.00 & \multirow[t]{6}{*}{0.58} \\
\hline & & & $(30.4)$ & & & & \\
\hline & $\mathrm{T} / \mathrm{G}$ & $186(47.9)$ & $136(48.6)$ & 1.12 & & 1.11 & \\
\hline & & & & $(0.79-1.59)$ & & $(0.78-1.59)$ & \\
\hline & $\mathrm{G} / \mathrm{G}$ & 72 & 59 & 1.25 & & 1.27 & \\
\hline & & (18.6) & (21.1) & $(0.81-1.95)$ & & $(0.81-1.97)$ & \\
\hline
\end{tabular}




\begin{tabular}{|c|c|c|c|c|c|c|c|}
\hline & G & 0.425 & 0.454 & 1.12 & 0.30 & 1.10 & 0.28 \\
\hline & & & & $(0.90-1.40)$ & & $(0.93-1.42)$ & \\
\hline \multirow{8}{*}{$\begin{array}{l}\text { rs761142 } \\
A>C\end{array}$} & \multirow[t]{2}{*}{$A / A$} & 228 & 148 (52.7) & 1.00 & \multirow[t]{6}{*}{0.12} & 1.00 & \multirow[t]{6}{*}{0.12} \\
\hline & & $(60.0)$ & & & & & \\
\hline & \multirow[t]{2}{*}{$\mathrm{A} / \mathrm{C}$} & \multirow[t]{2}{*}{$131(34.5)$} & \multirow[t]{2}{*}{$110(39.1)$} & 1.29 & & 1.28 & \\
\hline & & & & $(0.93-1.79)$ & & $(0.93-1.78)$ & \\
\hline & \multirow[t]{2}{*}{$\mathrm{C} / \mathrm{C}$} & 21 & 23 & 1.69 & & 1.71 & \\
\hline & & $(5.5)$ & $(8.2)$ & $(0.90-3.16)$ & & $(0.91-3.20)$ & \\
\hline & \multirow[t]{2}{*}{ C } & \multirow[t]{2}{*}{0.228} & \multirow[t]{2}{*}{0.278} & 1.30 & \multirow[t]{2}{*}{0.038} & 1.32 & \multirow[t]{2}{*}{0.032} \\
\hline & & & & $(1.01-1.68)$ & & $(1.02-1.70)$ & \\
\hline \multirow{3}{*}{\multicolumn{8}{|c|}{$\begin{array}{l}{ }^{1} \text { Absolute number and percentage of individuals/chromosomes with particular genotype } \\
2 \text { Odds ratio with } 95 \% \text { confidence intervals (crude analysis) with one degree of freedom. }\end{array}$}} \\
\hline & & & & & & & \\
\hline & & & & & & & \\
\hline \multicolumn{8}{|c|}{ NA, not available. } \\
\hline
\end{tabular}

Table 2Association of genotype combinations with the risk of CRC 


\begin{tabular}{|c|c|c|c|c|c|c|c|}
\hline \multirow[t]{2}{*}{ № } & \multirow[t]{2}{*}{ GCLCgenotype combination } & \multicolumn{2}{|c|}{$\begin{array}{l}\text { CRC } \\
\text { patients }\end{array}$} & \multicolumn{2}{|c|}{ Healthy controls } & \multirow[t]{2}{*}{ OR $(95 \% \mathrm{Cl})^{1}$} & \multirow[t]{2}{*}{$P^{2}$} \\
\hline & & $\mathrm{N}$ & $\%$ & $\mathrm{~N}$ & $\%$ & & \\
\hline G1 & rs12524494-G/A' rs761142-C/C & 9 & 3.2 & 2 & 0.6 & $\begin{array}{l}4.88 \\
(1.20-19.82)\end{array}$ & 0.03 \\
\hline G2 & rs12524494-G/A' rs606548-C/T & 27 & 10.4 & 13 & 3.9 & $\begin{array}{l}2.88 \\
(1.45-5.70)\end{array}$ & 0.002 \\
\hline G3 & rs636933-G/G ' rs761142-A/A & 138 & 49.5 & 213 & 57.4 & $\begin{array}{l}0.73 \\
(0.53-0.99)\end{array}$ & 0.04 \\
\hline G4 & rs636933-G/A 'rs606548-C/T & 10 & 3.8 & 3 & 0.8 & $\begin{array}{l}4.20 \\
(1.24-14.23)\end{array}$ & 0.02 \\
\hline G5 & rs636933-G/A 'rs17883901-G/A & 27 & 9.9 & 20 & 5.4 & $\begin{array}{l}1.94 \\
(1.06-3.54)\end{array}$ & 0.03 \\
\hline G6 & rs648595-G/T 'rs606548-C/T & 18 & 6.8 & 12 & 3.3 & $\begin{array}{l}2.13 \\
(1.01-4.51)\end{array}$ & 0.04 \\
\hline G7 & rs648595-G/T 'rs17883901-G/A & 25 & 9.2 & 18 & 4.7 & $\begin{array}{l}2.03 \\
(1.08-3.80)\end{array}$ & 0.02 \\
\hline G8 & rs761142-C/C 'rs606548-C/T & 10 & 3.8 & 3 & 0.8 & $\begin{array}{l}4.21 \\
(1.24-14.28)\end{array}$ & 0.02 \\
\hline G9 & rs606548-C/C 'rs17883901-G/G & 187 & 71.9 & 287 & 79.1 & $\begin{array}{l}0.68 \\
(0.47-0.98)\end{array}$ & 0.04 \\
\hline G10 & rs606548-C/T 'rs17883901-G/G & 26 & 10.0 & 17 & 4.7 & $\begin{array}{l}2.26 \\
(1.20-4.26)\end{array}$ & 0.01 \\
\hline \multicolumn{8}{|c|}{$\begin{array}{l}{ }^{1} \text { Odds ratio with } 95 \% \text { confidence intervals for particular genotype combination ( } \\
2 P \text {-values for association of particular genotype combination with CRC (Pearsor } \\
{ }^{3} Q \text {-values, adjusted } P \text {-values for multiple tests using false discovery rate (FDR); }\end{array}$} \\
\hline
\end{tabular}

Table 3. A summary on functional annotation of SNPs with Vannovarbioinformatics tools* 


\begin{tabular}{|c|c|c|c|c|c|c|c|}
\hline SNP ID & $\begin{array}{l}\text { Variant } \\
\text { Effect }\end{array}$ & $\begin{array}{l}\text { LD } \\
\text { information } \\
\text { (\#SNP in } \\
D \geq 0.9 \text { ) }\end{array}$ & $\begin{array}{l}\text { Roadmap } \\
\text { Epigenomics }^{1}\end{array}$ & $\begin{array}{l}\text { EpiMapEpigenomics } \\
2021^{2}\end{array}$ & $\begin{array}{l}\text { 3D } \\
\text { Genomes }^{3}\end{array}$ & $\begin{array}{l}\text { Pathogenicity } \\
\text { Score }^{4}\end{array}$ & $\begin{array}{l}\text { Oncogenicity } \\
\text { Score }^{4}\end{array}$ \\
\hline $\begin{array}{l}r s 12524494 \\
(A>G)\end{array}$ & intron & 14 & + & + & + & $\begin{array}{l}\text { likely } \\
\text { pathogenic } \\
\text { (fitCons) }\end{array}$ & $\begin{array}{l}\text { likely cancer } \\
\text { driver } \\
\text { (FunSeq2) }\end{array}$ \\
\hline $\begin{array}{l}r s 17883901 \\
(G>A)\end{array}$ & intron & 4 & + & + & + & $\begin{array}{l}\text { likely } \\
\text { pathogenic } \\
\text { (fitCons) }\end{array}$ & $\begin{array}{l}\text { likely cancer } \\
\text { driver } \\
\text { (FunSeq2) }\end{array}$ \\
\hline $\begin{array}{l}\text { rs606548 } \\
(\mathrm{C}>\mathrm{T})\end{array}$ & intron & 17 & + & + & + & $\begin{array}{l}\text { likely } \\
\text { pathogenic } \\
\text { (fitCons) }\end{array}$ & $\begin{array}{l}\text { likely cancer } \\
\text { driver } \\
\text { (FunSeq2) }\end{array}$ \\
\hline $\begin{array}{l}\text { rs636933 } \\
(G>A)\end{array}$ & intron & 8 & + & + & + & $\begin{array}{l}\text { likely } \\
\text { pathogenic } \\
\text { (fitCons) }\end{array}$ & $\begin{array}{l}\text { likely cancer } \\
\text { driver } \\
\text { (FunSeq2) }\end{array}$ \\
\hline $\begin{array}{l}r s 648595 \\
(T>G)\end{array}$ & intron & 19 & + & + & + & $\begin{array}{l}\text { likely } \\
\text { pathogenic } \\
\text { (fitCons) }\end{array}$ & $\begin{array}{l}\text { likely cancer } \\
\text { driver } \\
\text { (FunSeq2) }\end{array}$ \\
\hline $\begin{array}{l}\text { rs761142 } \\
(A>C)\end{array}$ & intron & 7 & + & + & + & $\begin{array}{l}\text { likely } \\
\text { pathogenic } \\
\text { (fitCons) }\end{array}$ & $\begin{array}{l}\text { likely cancer } \\
\text { driver } \\
\text { (FunSeq2) }\end{array}$ \\
\hline \multicolumn{8}{|c|}{$\begin{array}{l}{ }^{1} \text { Data on colon/rectum mucosal cells; }{ }^{2} \text { data on various cancer cells; }{ }^{3} \text { data on colorectal adenocarcinoma epithelial cells; }{ }^{4} \\
\text { predicted pathogenicity/oncogenicity (prediction score method);SNPs showed association with CRC are highlighted in gray. }\end{array}$} \\
\hline
\end{tabular}

Table 4 Tissue-specific eQTL analysis for polymorphisms of the GCLC gene from databases QTLGenand GTEx portal 


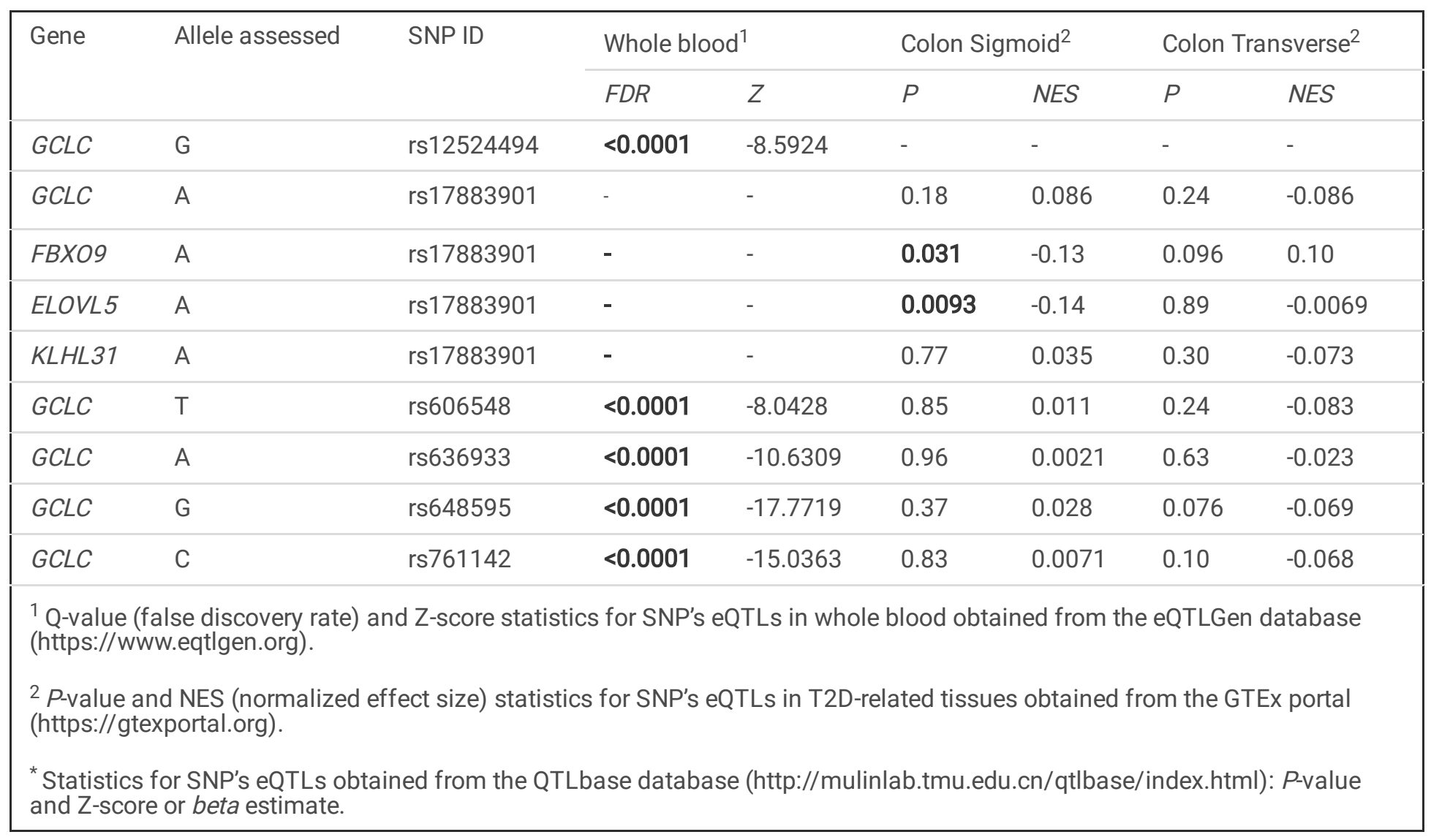

\section{Supplementary Files}

This is a list of supplementary files associated with this preprint. Click to download.

- Supplementarytables.docx 